\title{
On the age of the Harsány ignimbrite, Bükkalja volcanic field, Northern Hungary - a discussion
}

\author{
Szabolcs Harangi, Réka Lukács \\ Department of Petrology and Geochemistry, \\ Eötvös Loránd University, Budapest
}

\begin{abstract}
Correlation of scattered ignimbrite occurrences is crucial in the context of stratigraphy and the volcanic history of an area. In 2007, two papers were published concerning the classification of the volcanic rocks of the Bükkalja volcanic field. The interpretation of these papers shows an apparent contradiction in the age of the ignimbrite, which crops out at Tibolddaróc and Harsány. This paper attempts to resolve this contradiction. We show that the Harsány ignimbrite defined by Lukács et al. (2007) was indeed formed at 13.5 Ma and is not the same as was described by Márton et al. (2007). We redefine the possible locations of the Harsány and Tibolddaróc samples of Márton et al. (2007). The Tibolddaróc sample could represent the ash flow unit in the middle part of the Tibolddaróc volcanic section, whereas the Harsány sample could be derived from the 'Harsány-bend' outcrop. Both rocks have different geochemical character compared to the Harsány ignimbrite. This work emphasizes the usefulness of geochemical correlation of scattered rhyolitic ignimbrites, combined with detailed volcanological field observations.
\end{abstract}

Key words: Harsány ignimbrite, correlation, geochemistry, volcanology, Bükkalja, Miocene

\section{Introduction}

The Bükkalja volcanic field is a key area in understanding of Miocene silicic volcanism of the Carpathian-Pannonian region. The reason for this is that the products of the extensive Miocene silicic volcanism are at surface and show a remarkably fresh character. This is in contrast to what is usually found in the borehole drilling cores. The Miocene Si-rich pyroclastic rocks were formed over a fairly long period in the Pannonian Basin from 21 Ma to 13 Ma (Pécskay et al. Address: $\quad \begin{aligned} & \text { Sz. Harangi, R. Lukács: H-1117 Budapest, Pázmány Péter sétány 1/C, Hungary } \\ & \text { e-mail: szabolcs.harangi@geology.elte.hu }\end{aligned}$

Received: June 8, 2009; accepted: June 30, 2009 
2006). This means that this volcanism partly predates, and is partly contemporaneous, with the main rifting period of the Pannonian Basin (Harangi and Lenkey 2007).

Explosive volcanic eruptions of large volume magmas represent instantaneous geologic events; consequently they provide unique chronological marker horizons in stratigraphic sections on a regional scale. In the Pannonian Basin, three main volcanic horizons were traditionally distinguished: the lower, middle and upper rhyolite tuff, which correspond to the lithostratigraphic units of Gyulakeszi Rhyolite Tuff, the Tar Dacite Tuff and the Galgavölgy Rhyolite Tuff, respectively (Schréter 1913; Noszky 1931, 1936; Hámor et al. 1980, 1987; Márton and Pécskay 1998). In the Bükkalja volcanic field, Szakács et al. (1998) denoted them as Lower, Middle and Upper Rhyolite Tuff Complex. Recent work has, however, emphasized the more complex character of this volcanism and suggested repeated eruptions of different magmas even contemporaneously (e.g. Lukács et al. 2002, 2007, 2010; Harangi et al. 2005).

The threefold character of the silicic volcanism appears to be reflected excellently in the Bükkalja volcanic field, where the paleomagnetic rotation data clearly distinguish three main units (Márton and Márton 1996; Márton and Pécskay 1998; Márton et al. 2007). This is due to the observation that two main rotation events occurred during this long lasting volcanism (Márton and Fodor 1995). This makes the paleomagnetic data a useful tool in the correlation studies in the Northern part of the Pannonian Basin and particularly in the Bükkalja volcanic field. Recently, Márton et al. (2007) published a compilation of paleomagnetic data for the silicic pyroclastic rocks from Bükkalja and proposed a revised classification of the scattered occurrences. This work includes several new results and interpretations. Among them, Márton et al. (2007) classified the ignimbrites from Harsány and Tibolddaróc (Fig. 1) as belong to the upper part of the Middle Tuff Complex instead of the Upper Rhyolite Tuff Complex; thus, they could have been formed at about $16 \mathrm{Ma}$. This conclusion is just the opposite of what was proposed by Lukács et al. (2007) in a study published in the same year. Lukács et al. (2007) defined the Harsány ignimbrite as a distinct volcanic unit occurring mostly at Harsány and Tibolddaróc (Fig. 1) and formed at 13.5 Ma. This short discussion paper attempts to resolve this apparent contradiction and emphasizes the correlation power of the detailed volcanological and geochemical observations.

\section{Data and interpretation provided by Márton et al. (2007)}

Márton et al. (2007) published paleomagnetic results based on measurements of more than 150 samples from 28 sites around the Bükk Mts. Among them they presented two new data from north of Harsány (sample name: 7721-728) and from Tibolddaróc (sample name: 8902-911). Unfortunately the precise location and stratigraphic position of the samples are not given in the paper. The sample 


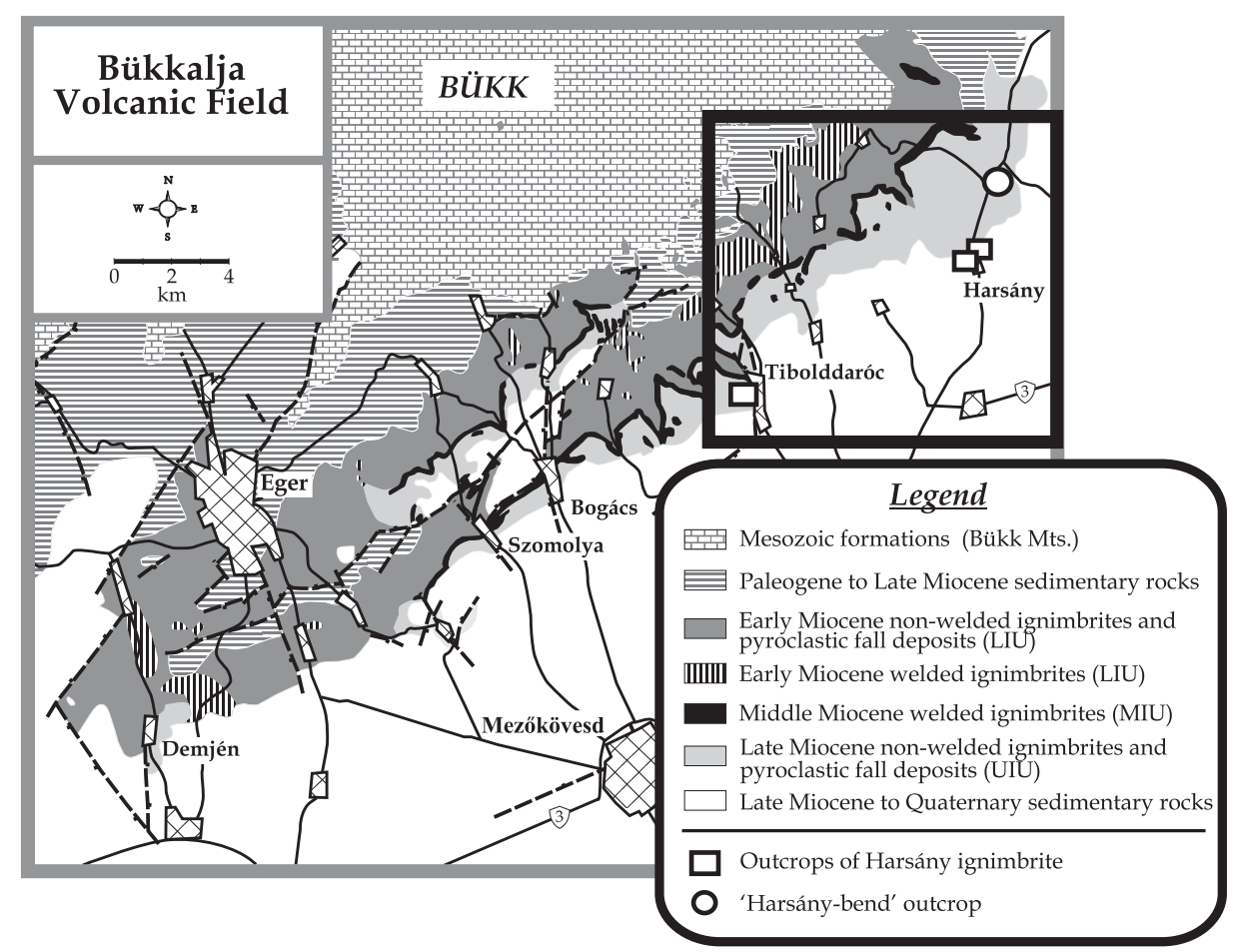

Fig. 1

Location of the outcrops discussed in the text (after Harangi et al. 2005)

from Harsány is described as a non-welded dacite-rhyolite ignimbrite, whereas that from Tibolddaróc is a slightly welded rhyolitic ignimbrite with lapilli, which contains biotite and amphibole (Table 1 of Márton et al. 2007). The declination of the Harsány sample is $145^{\circ}$ and that of the Tibolddaróc one is $313^{\circ}$, which suggests similar rotation (about $35^{\circ} \mathrm{CCW}$ ), but reverse and normal polarities, respectively. These data are consistent with formation just before the second CCW rotation event, i.e. at the top of the Middle rhyolite unit, at about $16 \mathrm{Ma}$.

\section{Data and interpretation provided by Lukács et al. (2007)}

Lukács et al. (2007) defined the Harsány ignimbrite unit at two localities (Fig. 1). This rock occurs in Harsány, at the northern end of the village and its western part, along the wine cellars. They are unwelded pumice-bearing lapilli tuff (ignimbrite) with high-Si rhyolitic composition. It is important to note that Lukács et al. (2007) described another ignimbrite outcrop at Harsány. This is about $2 \mathrm{~km}$ north of the village on the right side of the road, before the crossroad to Bükkaranyos (Fig. 1). This outcrop is called the 'Harsány-bend' ('Harsánykanyar') or North Harsány outcrop. It also exposes rhyolitic lapilli tuff, 


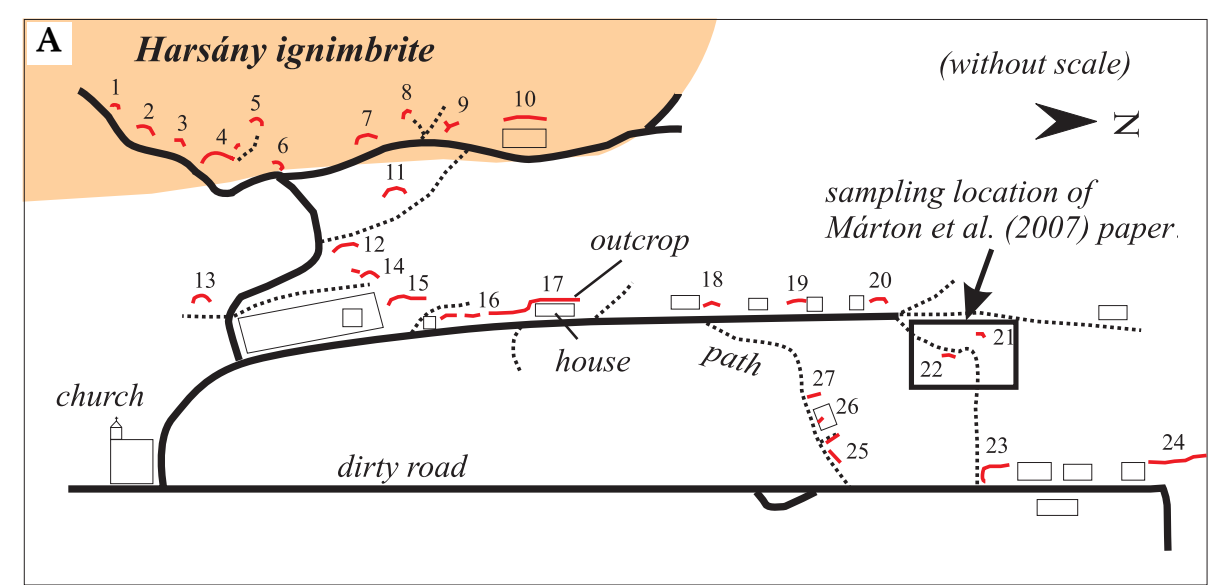

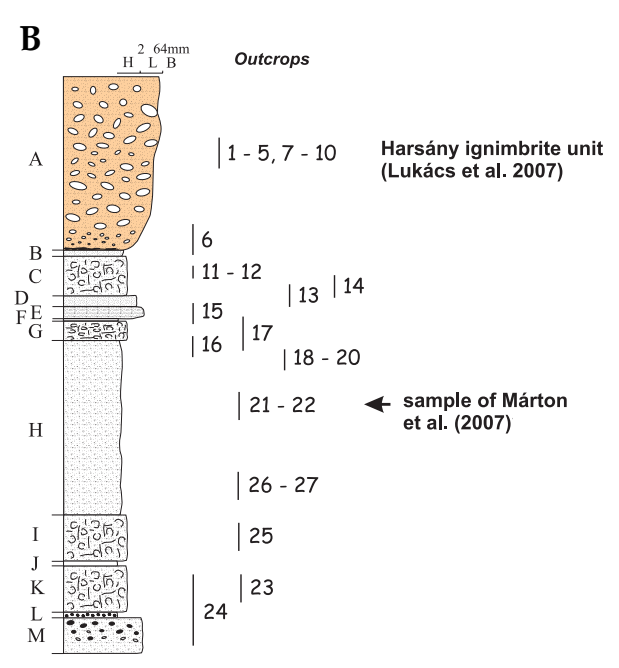

Fig. 2

A. Simplified map of the outcrops at the western part of Tibolddaróc, delineating the Harsány ignimbrite unit (Lukács et al. 2007) and showing the possible location of the sampling point of Márton et al. (2007). B. Interpreted volcanostratigraphic section of the Tibolddaróc locality, indicating the position of the Harsány ignimbrite unit (Lukács et al. 2007) and the possible position of the sample analyzed by Márton et al. (2007) interpreted as unwelded ignimbrite. However, it differs significantly from those that are found in Harsány village, based on the composition of the mineral phases and the glass shards (e.g. Fig. 9. from Lukács et al. 2007). Therefore, the 'Harsány-bend' ignimbrite represents a separate volcanic unit and does not belong to the defined Harsány ignimbrite unit.

The other occurrence of the Harsány ignimbrite is situated in the western part of Tibolddaróc, along the wine cellars. Here this unit overlays a series of pyroclastic layers (Fig. 2). The bottom of this succession is represented by a mixed scoria/pumicebearing pyroclastic flow deposit, a characteristic formation of the Middle Tuff Complex (Czuppon et al. 2001). The following section includes alternating rhyolitic tuff and lapilli tuff layers, as well as reworked beds. The uppermost thick unit of this volcanic succession shows remarkable similarities with the rhyolitic pyroclastic rocks from Harsány village. The most characteristic fingerprints of these rocks are the large pumice blocks, often including pale violet quartz crystals, the bimodal compositional character of the pumice and the biotite, the sodic 
composition of the plagioclase and the dominantly iron-rich composition of the biotite. In addition the trace element pattern of the glass shards is unique within the Bükkalja volcanic units (Fig. 11 in Lukács et al. 2007). Lukács et al. (2007) presented K/Ar radiometric age data measured on separated biotite fractions from samples collected at the two localities. The data (13.65 $\pm 0.72 \mathrm{Ma}$ and $13.35 \pm$ $1.01 \mathrm{Ma}$ ) show that this volcanic unit was formed about 13.5 Ma.

\section{Reinterpretation of the result by Márton et al. (2007)}

It is clear that there is a major contradiction between the interpretations of the two papers on the age of the ignimbrite occurring at Harsány and Tibolddaróc. We have no doubts that the data, both the paleomagnetic and the volcanological/ geochemical ones are correct. Nevertheless, we must note that in the Tibolddaróc section there is no welded facies of the ignimbrite facies, as indicated by the general occurrence of cuspate, occasionally vesicular glass shards and the lack of fiamme. Furthermore, within the entire section, amphibole is not a characteristic mineral, although it occurs as subordinate accessory mineral in certain layers in the middle parts. It is more common in the lowermost mixed scoria/pumicebearing pyroclastic rock. We are sure that the sample that Márton et al. (2007) analyzed could not be derived from the uppermost layer of the Tibolddaróc section; therefore it does not represent the Harsány ignimbrite unit. This sample might be one collected during joint field work with Emő Márton, i.e. from unit H (site 21-22) of the Tibolddaróc section, as defined by Lukács et al. (2007) and shown in Fig. 2. In that case, this sample is certainly older than unit A, which belongs to the Harsány ignimbrite unit.

At Harsány, the two localities within the village consist of loose pumice-bearing lapilli tuff, which are not suitable for paleomagnetic measurement. However, the exposed rocks from both outcrops show striking similarities with that of unit $\mathrm{A}$ in the Tibolddaróc section and thus interpreted as belonging to the same eruptive unit, called the Harsány ignimbrite (Lukács et al. 2007). The Harsány sample presented by Márton et al. (2007) cannot be derived from these outcrops. A possible explanation for the origin of their sample is the 'Harsány-bend' outcrop. It is better cemented; therefore it might be more suitable for paleomagnetic sampling. This rock also consists of pumice-bearing lapilli tuff and represents an ignimbrite flow. However, the composition of glass shards and the mineral phases differs from those of the Harsány ignimbrite (Fig. 3). In that case the age of this deposit is also different, possibly older than $13.5 \mathrm{Ma}$. It is remarkable that the trace element pattern of the glass shard from a sample of the unit $\mathrm{H}$ ash flow from Tibolddaróc and from a sample of the 'Harsány-bend' shows a remarkable similarity (Fig. 4). Thus, it is possible that these two rocks could belong to the same eruptive unit. In that case, Márton et al. (2007) determined the age of an ignimbrite that is about $16 \mathrm{Ma}$, and thus much older than the Harsány ignimbrite unit (13.5 Ma; Lukács et al. 2007). 

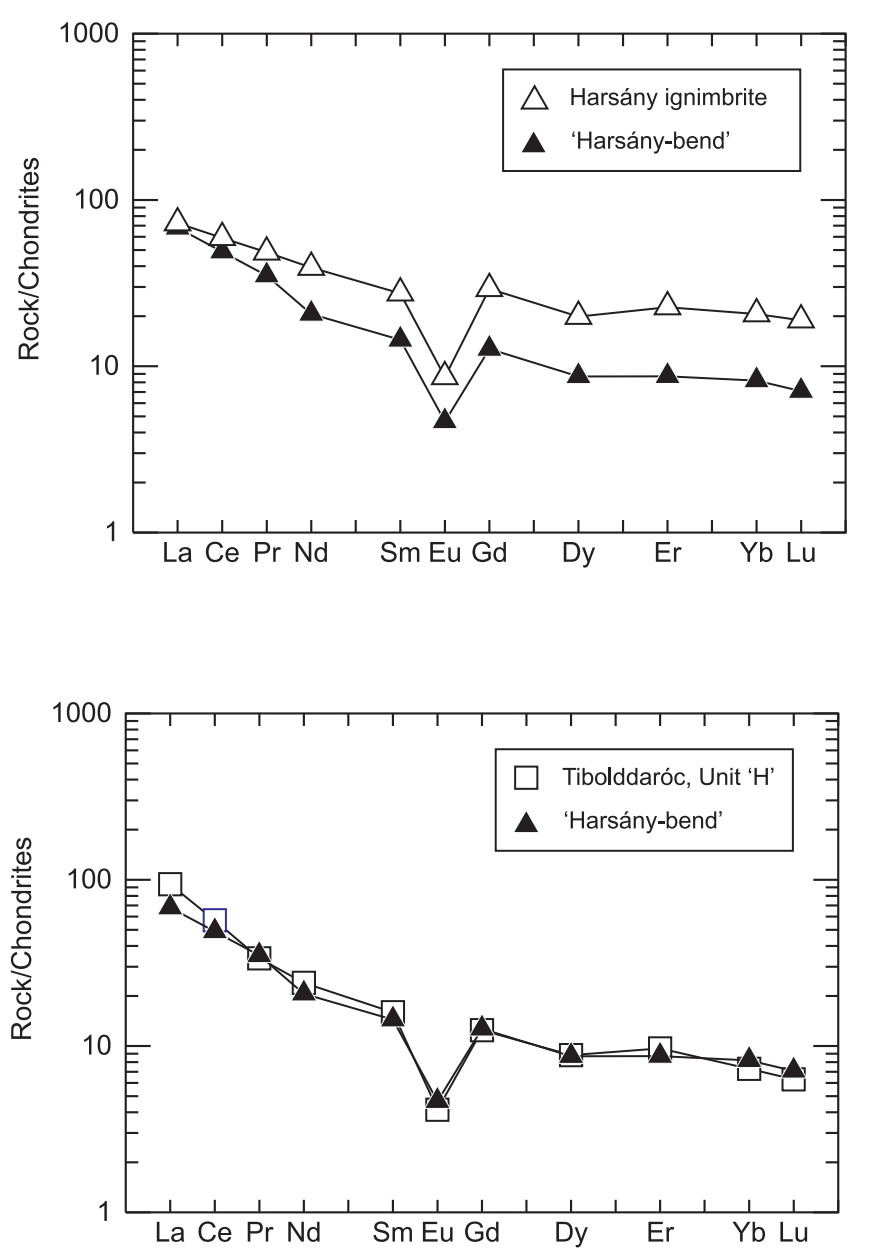

Fig. 3

Chondrite (Sun and McDonough 1989) normalized rare earth element pattern of a representative glass shard from the Harsány ignimbrite and from the 'Harsány-bend' locality

Fig. 4

Chondrite (Sun and McDonough 1989) normalized rare earth element pattern of a representative glass shard from unit $\mathrm{H}$ from Tibolddaróc and from the 'Harsány-bend' locality

\section{Conclusion}

Correlation of scattered occurrences of extended ignimbrite deposits is crucial in understanding the broad stratigraphic framework of an area, but also in revealing its volcanic history. There are a couple of powerful correlation tools, which can be applied differently in certain regions. Márton et al. (2007) stated that in Northern Hungary and particularly in the Bükkalja area, the paleomagnetic declination data were the best guidelines in distinguishing between the three ignimbrite complexes and were far more reliable than correlation by chemical composition. We agree partly with this statement, but as we emphasized previously in many papers (e.g. Lukács et al. 2001, 2007; Harangi et al. 2005) and also in this work, geochemistry and field observations can be as 
powerful correlation tools as the paleomagnetic data. This is especially true in those cases where the volcanic eruptions occurred between two main rotation events and provided volcanic rocks with distinct mineral and bulk rock chemical compositions, or when the pyroclastic rocks are not suitable for paleomagnetic measurement. We point out that detailed volcanological field observations combined with geochemical data can help resolve apparent contradictions, as reflected in the papers published by Márton et al. (2007) and Lukács et al. (2007). We conclude that the Harsány ignimbrite was formed at about $13.5 \mathrm{Ma}$ and represents the youngest member of the Bükkalja ignimbrites. On the other hand, spatially close to this volcanic unit, pyroclastic rocks with fairly similar appearance are found, what was possibly measured by Márton et al. (2007) with the paleomagnetic method and proved to be older (about $16 \mathrm{Ma}$ ). Geochemical differences emphasize the distinction between these two units.

\section{Acknowledgements}

The field works in the Bükkalja volcanic field were supported by several research projects, such as the bilateral Hungarian-Italian joint work in 1993-1995, the Pro Renovanda Culturae Foundation (DT.2001.nov./21) granted to the second author, an Austrian-Hungarian Action Grant, and an Austrian-Hungarian Exchange Program (TET) from 2000 to 2004. The microprobe work was carried out at the Institute of Lithospheric Studies, University of Vienna (Austria) during this joint research, and determination of trace element content of the glass shards by laser ablation ICP-MS was carried out in the course of a NATO fellowship grant to the senior author. Theodoros Ntaflos and Paul Mason are thanked for help in these measurements. T. Póka and J. Földessy are thanked for the review of the manuscript.

\section{References}

Czuppon, G., Sz. Harangi, T. Ntaflos, R. Lukács, C. Szabó, F. Koller 2001: Mixed andesite-rhyolite ignimbrite from the Miocene Bükkalja Ignimbrite Volcanic Field, Northern Hungary: evidence for magma mixing. - Mitteilungen der Österreichischen Mineralogischen Gesellschaft, 146, pp. 61-63.

Harangi, Sz., L. Lenkey 2007: Genesis of the Neogene to Quaternary volcanism in the Carpathian-Pannonian Region: role of subduction, extension and mantle plume. - In: Beccaluva, L., G. Bianchini, M. Wilson (Eds): Cenozoic volcanism in the Mediterranean area, Geological Society of America Special Paper 418, pp. 67-92.

Harangi, Sz., P.R.D. Mason, R. Lukács 2005: Correlation of silicic pyroclastic rocks in the Northern Pannonian Basin, Eastern-Central Europe: a geochemical approach. - Journal of Volcanology and Geothermal Research, 143, pp. 237-257.

Hámor, G., L. Ravaszné Baranyai, K. Balogh, E. Árva Soós 1980: Radiometric age of the Miocene rhyolite tuff horizons in Hungary. - MÁFI Évi Jelentése 1978-ról, pp. 65-73. (In Hungarian.)

Hámor, G., L. Ravasz-Baranyai, J. Halmai, K. Balogh, E. Árva Sós 1987: Dating of Miocene acid and intermediate volcanic activity in Hungary. - Ann. inst. Geol. Publ. Hung., 70, pp. 149-154. 
Lukács, R., Sz. Harangi, I. Oláh 2001: Correlation of Miocene pumice-bearing pyroclastic deposits in the Pannonian Basin.- Mitteilungen der Österreichischen Mineralogischen Gesellschaft, 146, pp. $180-182$.

Lukács, R., Gy. Czuppon, Sz. Harangi, Cs. Szabó, T. Ntaflos, F. Koller 2002: Silicate melt inclusions in ignimbrites, Bükkalja Volcanic Field, Northern Hungary - texture and geochemistry. - Acta Geol. Hung., 45/4, pp. 341-358.

Lukács, R., Sz. Harangi, T. Ntaflos, F. Koller, Z. Pécskay 2007: The characteristics of the Upper Rhyolite Tuff Horizon in the Bükkalja Volcanic Field: The Harsány ignimbrite unit. - Földtani Közlöny, 137, pp. 487-514. (In Hungarian with English abstract.)

Lukács, R., Sz. Harangi, Gy. Radócz, M. Kádár, Z. Pécskay, T. Ntaflos 2010: The nature of the Miocene volcanic products of the boreholes Miskolc-7, Miskolc-8 and Nyékládháza-1 and their correlation with the ignimbrites of Bükkalja - Földtani Közlöny, 140 pp. 445-468. (In Hungarian with English abstract.)

Márton, E., L. Fodor 1995: Combination of paleomagnetic and stress data - a case study from North Hungary. - Tectonophysics, 242, pp. 99-114.

Márton E., Z. Pécskay 1998: Complex evaluation of paleomagnetic and K/Ar isotope data of the Miocene ignimbritic volcanics in the Bükk Foreland, Hungary. - Acta Geol. Hung., 41, pp. 467-476.

Márton, E., P. Márton 1996: Large scale rotation in North Hungary during the Neogene as indicated by paleomagnetic data. - In: Morris, A., D.H. Tarling (Eds): Paleomagnetism and Tectonics of the Mediterranean Region. - Geological Society, Special Publications, 105, pp. 153-173.

Márton, E., T. Zelenka, P. Márton 2007: Paleomagnetic correlation of Miocene pyroclastics of the Bükk Mts. and their forelands. - Central European Geology 50, pp. 47-57.

Noszky, J. 1931: The Oligocene-Miocene stratigraphy of the northeastern part of the Hungarian Mid-Mountains: II. The Miocene. - Ann. Mus. Nat. Hung. 27, pp. 160-236. (In Hungarian.)

Noszky, J. 1936: Contribution with data to the geology of northern and middle parts of Cserhát. Jelentés az 1936. évi reambulációs felvételrôl. (In Hungarian.)

Pécskay, Z., L. Lexa, A. Szakács, I. Seghedi, K. Balogh, V. Konecny, T. Zelenka, M. Kovacs, T. Póka, A. Fülöp, E. Márton, C. Panaiotu, V. Cvetkovic 2006: Geochronology of Neogene magmatism in the Carpathian arc and intra-Carpathian area. - Geologica Carpathica, 57, pp. 511-530.

Schréter, Z. 1913: Geology of Eger and surrounding. - MÁFI Évi Jelentése 1912-rôl, pp. 130-146. (In Hungarian.)

Sun, S.S., W.F McDonough 1989: Chemical and isotopic systematics of oceanic basalts: implications for mantle composition and processes. - In: Saunders, A.D., M.J. Norry (Eds): Magmatism in the oceanic basins. Geol. Soc. Spec. Publ. No. 42, pp. 313-345.

Szakács, A., T. Zelenka, E. Márton, Z. Pécskay, T. Póka, I. Seghedi 1998: Miocene acidic explosive volcanism in the Bükk Foreland, Hungary: Identifying eruptive sequences and searching for source locations. - Acta Geol. Hung., 41/4, pp. 413-435. 